Article

\title{
Exhausted Woods from Tannin Extraction as an Unexplored Waste Biomass: Evaluation of the Antioxidant and Pollutant Adsorption Properties and Activating Effects of Hydrolytic Treatments
}

\author{
Lucia Panzella ${ }^{1, *} \oplus$, Federica Moccia ${ }^{1}$, Maria Toscanesi ${ }^{1}$, Marco Trifuoggi ${ }^{1}$, Samuele Giovando ${ }^{2}$ \\ and Alessandra Napolitano ${ }^{1}$ (1) \\ 1 Department of Chemical Sciences, University of Naples “Federico II", Via Cintia 4, I-80126 Naples, Italy; \\ federica.moccia@unina.it (F.M.); maria.toscanesi@unina.it (M.T.); marco.trifuoggi@unina.it (M.T.); \\ alesnapo@unina.it (A.N.) \\ 2 Centro Ricerche per la Chimica Fine Srl for Silvateam Spa, Via Torre 7, 12080 San Michele Mondovì, CN, \\ Italy; sgiovando@silvateam.com \\ * Correspondence: panzella@unina.it; Tel.: +39-081-674131
}

Received: 5 February 2019; Accepted: 28 March 2019; Published: 1 April 2019

\begin{abstract}
Exhausted woods represent a byproduct of tannin industrial production processes and their possible exploitation as a source of antioxidant compounds has remained virtually unexplored. We herein report the characterization of the antioxidant and other properties of practical interest of exhausted chestnut wood and quebracho wood, together with those of a chestnut wood fiber, produced from steamed exhausted chestnut wood. 2,2-Diphenyl-1-picrylhydrazyl (DPPH) and ferric reducing/antioxidant power (FRAP) assays indicated good antioxidant properties for all the materials investigated, with exhausted chestnut wood, and, even more, chestnut wood fiber exhibiting the highest activity. High efficiency was observed also in the superoxide scavenging assay. An increase of the antioxidant potency was observed for both exhausted woods and chestnut wood fiber following activation by hydrolytic treatment, with an up to three-fold lowering of the $\mathrm{EC}_{50}$ values in the DPPH assay. On the other hand, exhausted quebracho wood was particularly effective as a nitrogen oxides $\left(\mathrm{NO}_{\mathrm{x}}\right)$ scavenger. The three materials proved able to adsorb methylene blue chosen as a model of organic pollutant and to remove highly toxic heavy metal ions like cadmium from aqueous solutions, with increase of the activity following the hydrolytic activation. These results open new perspectives toward the exploitation of exhausted woods as antioxidants, e.g., for active packaging, or as components of filtering membranes for remediation of polluted waters.
\end{abstract}

Keywords: agri-food waste; exhausted wood; antioxidant; DPPH assay; FRAP assay; tannins; heavy metals; methylene blue; nitric oxides; acid hydrolysis

\section{Introduction}

In the light of their marked antioxidant properties, phenolic polymers from natural sources have been the focus of increasing interest as sustainable functional materials for the wide range of potential applications, for example as biocompatible materials for biomedical devices or as active components in functional food packaging [1-7]. Indeed, phenolic polymers display manifold advantages over their monomers, including higher stability properties thus offering easier handling and processing, as well as lower solubility reducing tendency to be released $[4,8,9]$.

Among natural phenolic polymers, tannins occupy a prime position given the well-established antimicrobial and protein binding properties [1,10-14]. Tannins are traditionally ranked into the 
hydrolyzable and the condensed or non-hydrolyzable classes. Castanea sativa wood extract, commonly known as chestnut tannin, is composed mainly of hydrolyzable ellagitannins such as castalagin and its isomer vescalagin, whereas quebracho tannin, extracted from the hardwood of Shinopsis balansae/lorentzii, comprise mainly condensed tannins of which linear profisetinidins represent the major constituents (Figure 1) [1,15,16].

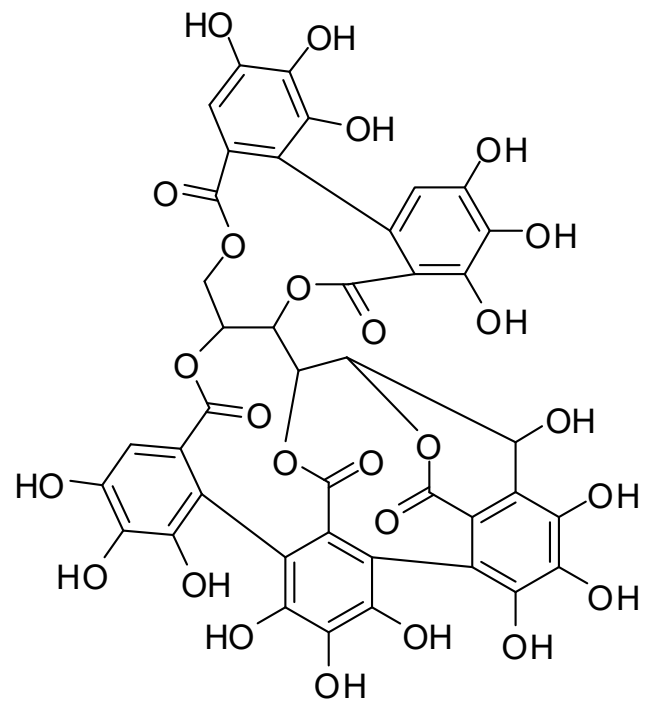

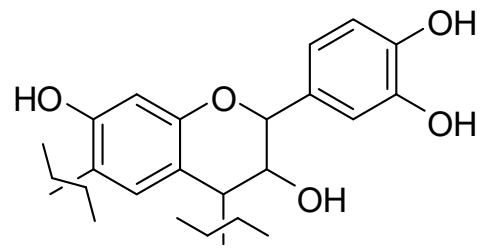

Profisetinidins

\section{Castalagin/vescalagin}

Figure 1. Representative structures of the main tannins occurring in chestnut and quebracho wood.

Both chestnut and quebracho tannins are commonly employed not only in the tanning industry, but also in the oenological, cosmetic, and pharmaceutical field as well as in products for animal feed [1,17-23]. Tannin extraction from wood is generally performed in hot water. The residual wood biomasses (exhausted woods), a by-product of the tannin extraction process, may be taken as renewable sources in their own right, since the wood has been treated only with hot water at high pressure, a treatment that is not expected to result in any significant change of the structural components. These exhausted woods are commonly used in the production of pellets for heating and energy production. The isolation of cellulose nanocrystals to be used e.g., as nanofillers for polymer composites from the exhausted acacia bark, obtained after the industrial process of extracting tannin, has also been reported [24]. However, the possible exploitation as antioxidant materials has remained virtually unexplored.

We report herein the characterization of the antioxidant properties of exhausted chestnut and quebracho wood, together with those of a chestnut wood fiber produced from steamed exhausted chestnut wood. The materials investigated are shown in Figure 2. For comparison, the corresponding fresh woods and tannins were investigated as well. Exhausted woods and chestnut wood fiber were also tested for their ability to remove environmental pollutants, either organic compounds or toxic heavy metals. Based on recent findings showing that acid hydrolytic treatment of natural phenolic polymers or wastes leads to materials with potent antioxidant efficiency $[4,25,26]$, we also investigated the properties of the exhausted woods and chestnut wood fiber materials obtained by such treatment in comparison with those of the untreated materials, showing in most cases a significant enhancement of the activity. The results obtained open new perspectives for the exploitation of these by-products e.g., in active packaging or for remediation of polluted waters. 


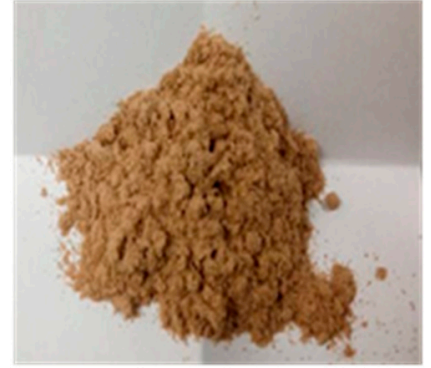

(a)

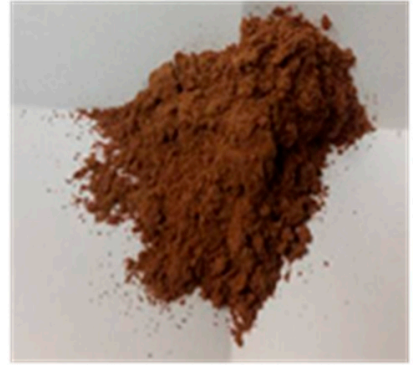

(b)

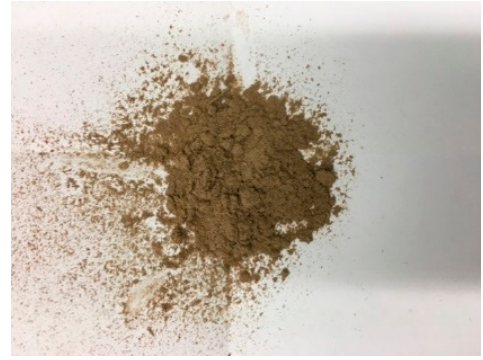

(c)

Figure 2. (a) Exhausted chestnut wood; (b) exhausted quebracho wood; (c) chestnut wood fiber.

\section{Materials and Methods}

\subsection{General Experimental Methods}

Chestnut and quebracho exhausted and fresh woods, chestnut wood fiber as well as chestnut and quebracho tannins were provided by Silvateam (Via Torre, S. Michele Mondovì, Cuneo, Italy). In particular, fresh chestnut and quebracho woods were obtained from hardwood of Castanea sativa and Schinopsis lorentzii respectively, and reduced in chips of ca. 1-3 cm. Tannins were obtained by soaking the wood chips in autoclaves with water, at $120^{\circ} \mathrm{C}$, under pressure; the extracts thus obtained were concentrated with a multiple-effect evaporator under vacuum until ca. 50\% water was removed, and tannin powder finally obtained by spray-drying. Residual chips after the extraction were stored as exhausted woods. Chestnut wood fiber was obtained from chestnut exhausted wood after drying in oven overnight at $60^{\circ} \mathrm{C}$ and milling to obtain $<250 \mu \mathrm{m}$ particles.

2,2-Diphenyl-1-picrylhydrazyl (DPPH), iron (III) chloride (97\%), 2,4,6-tris(2-pirydyl)-s-triazine (TPTZ) ( $\geq 98 \%),( \pm)-6$-hydroxy-2,5,7,8-tetramethylchromane-2-carboxylic acid (Trolox) (97\%), ethylenediaminetetraacetic acid (EDTA) (>99\%), nitroblue tetrazolium (NBT) chloride $(98 \%)$, pyrogallol $\left(\geq 98 \%\right.$ ), quercetin ( $\geq 95 \%$ ), fluorescein, $2,2^{\prime}$-azobis(2-methylpropionamidine) dihydrochloride (AAPH) $(97 \%)$, Folin \& Ciocalteu's phenol reagent $(2 \mathrm{~N})$, gallic acid $(\geq 97.5 \%)$, activated carbon, sodium nitrite ( $\geq 97.0 \%), N$-(1-naphthyl)ethylenediamine dihydrochloride ( $\geq 98 \%)$, sulfanilamide ( $\geq 99 \%)$, methylene blue (MB), cadmium carbonate $(99 \%)$, and nitric acid $\left(\geq 69 \% \mathrm{v} / \mathrm{v}\right.$, TraceSELECT ${ }^{\circledR}$ water solution) were obtained from Sigma-Aldrich (Milan, Italy) and used as obtained.

UV-Vis spectra were performed using a HewlettPackard 8453 Agilent spectrophotometer.

Fluorescence spectra were record on a HORIBA Jobin Yvon Inc. FluoroMax ${ }^{\circledR}-4$ spectrofluorometer.

For metal removal experiments, $1 \% \mathrm{HNO}_{3}, 0.1 \mathrm{M} \mathrm{HCl}$ and $0.01 \mathrm{M}$ phosphate buffer ( $\mathrm{pH} 7.0$ ) were prepared using ultrapure deionized water with conductivity $<0.06 \mu \mathrm{S} / \mathrm{cm}$. All glassware used were carefully washed first with a $1 \% \mathrm{HNO}_{3}$ solution and then with ultrapure deionized water. Metal analysis was carried out on an inductively coupled plasma mass spectrometry (ICP-MS) instrument Aurora M90 model by Bruker.

\subsection{Hydrolytic Treatment}

The proper material $(3 \mathrm{~g})$ was treated with $70 \mathrm{~mL}$ of $6 \mathrm{M} \mathrm{HCl}$ under stirring at $100^{\circ} \mathrm{C}$ overnight $[4,26]$. After cooling at room temperature, the mixture was centrifuged $(8247 \times g$, room temperature, $15 \mathrm{~min})$ and the precipitate washed with water until neutrality and freeze dried. The recovery yields were $58 \%$ (chestnut wood fiber), 68\% (exhausted chestnut wood) and 83\% (quebracho exhausted wood).

\subsection{DPPH Assay}

To a $0.2 \mathrm{mM}$ methanolic solution of DPPH wood or tannin powders were added (final dose $0.03-1.5 \mathrm{mg} / \mathrm{mL}$ ) and after $10 \mathrm{~min}$ under stirring at room temperature the absorbance of the solution at $515 \mathrm{~nm}$ was measured $[27,28]$. Experiments were run in triplicate. Trolox was used as reference antioxidant. 


\subsection{Ferric Reducing/Antioxidant Power (FRAP) Assay}

To $0.3 \mathrm{M}$ acetate buffer ( $\mathrm{pH}$ 3.6) containing $1.7 \mathrm{mM} \mathrm{FeCl}_{3}$ and $0.83 \mathrm{mM} \mathrm{TPTZ}$, wood or tannin powders (final dose $0.00625-0.3 \mathrm{mg} / \mathrm{mL}$ ) were added and after $10 \mathrm{~min}$ under stirring at room temperature the absorbance of the solution at $593 \mathrm{~nm}$ was measured [29]. Results were expressed as Trolox equivalents. Experiments were run in triplicate.

\subsection{Superoxide Scavenging Assay}

Wood or tannin powders (final dose $0.0625 \mathrm{mg} / \mathrm{mL}$ ) were added to $0.05 \mathrm{M}$ ammonium hydrogen carbonate buffer ( $\mathrm{pH}$ 9.3) containing $0.4 \mathrm{mM}$ EDTA and $12 \mu \mathrm{M}$ NBT, followed by a $20 \mathrm{mM}$ pyrogallol solution in $0.05 \mathrm{mM} \mathrm{HCl}$ (final pyrogallol concentration $3.3 \mathrm{mM}$ ) [4,30]. The mixture was vigorously stirred for $5 \mathrm{~min}$, after that absorbance at $596 \mathrm{~nm}$ was measured. Results were expressed as percentage of reduction of the absorbance at $596 \mathrm{~nm}$ of a control mixture run in the absence of sample. Experiments were run in triplicate.

\subsection{Oxygen Radical Antioxidant Capacity (ORAC Assay)}

Wood or tannin powders (final dose $0.075 \mathrm{mg} / \mathrm{mL}$ ) were incubated in a $62.7 \mu \mathrm{M}$ fluorescein solution in $75 \mathrm{mM}$ phosphate buffer ( $\mathrm{pH} 7.4$ ) for $30 \mathrm{~min}$, at $37^{\circ} \mathrm{C}$. A $153 \mathrm{mM} \mathrm{AAPH}$ solution was then added (final APPH concentration $19 \mathrm{mM}$ ) and after stirring at $37^{\circ} \mathrm{C}$ for 45 min fluorescence was measured $\left(\lambda_{\mathrm{ex}}=485 \mathrm{~nm}, \lambda_{\mathrm{em}}=511 \mathrm{~nm}\right)$ [31]. Results were expressed as relative fluorescence intensity with respect to a control mixture run in the absence of APPH. Experiments were run in triplicate.

\subsection{MB Adsorption Assay}

Adsorption experiments were performed at room temperature by adding wood samples $(0.2 \mathrm{mg} / \mathrm{mL})$ to a 5 or $25 \mathrm{mg} / \mathrm{L}$ aqueous solution of $\mathrm{MB}$. The mixtures were taken under stirring and after $30 \mathrm{~min}$ the absorbance at $654 \mathrm{~nm}$ was measured [32]. Activated carbon was used as reference material. Experiments were run in triplicate.

\subsection{Nitric oxides $\left(\mathrm{NO}_{x}\right)$ Scavenging Assay}

A solution of sodium nitrite $(1 \mathrm{M})$ in water was added to $10 \%$ sulfuric acid over $10 \mathrm{~min}$ [33]. The red orange gas that developed $(0.2-0.6 \mathrm{~mL})$ was withdrawn with a syringe and conveyed through a tip containing $5 \mathrm{mg}$ of wood sample into $3 \mathrm{~mL}$ of Griess reagent $(0.5 \%$ sulfanilamide and $0.05 \%$ $N$-(1-naphthyl)ethylenediamine dihydrochloride in $1.25 \%$ phosphoric acid) and the absorbance at $540 \mathrm{~nm}$ was measured. Experiments were run in triplicate.

\section{9. $C d^{2+}$ Adsorption}

A $1.5 \mathrm{mM}$ stock solution of the heavy metal was prepared by dissolving $10 \mathrm{mg}$ of cadmium carbonate in $39 \mathrm{~mL}$ of $0.1 \mathrm{M} \mathrm{HCl}$. Prior to the adsorption experiments a $1.5 \mathrm{mg} / \mathrm{mL}$ suspension of each wood sample in $0.01 \mathrm{M}$ phosphate buffer ( $\mathrm{pH}$ 7.0) was obtained by homogenization in a Tenbroeck glass to glass homogenizer for $4 \mathrm{~min}$. $0.7 \mathrm{~mL}$ of the wood suspensions and $0.1 \mathrm{~mL}$ of the metal solution were added to $10 \mathrm{~mL}$ of $0.01 \mathrm{M}$ phosphate buffer at $\mathrm{pH} 7.0$. After $2 \mathrm{~h}$, the mixtures were filtered through a $0.45 \mu \mathrm{m}$ nylon membrane, acidified by addition of $69 \%$ nitric acid (1:100 $v / v)$, properly diluted with $1 \%$ nitric acid, and analyzed by ICP-MS [34]. A calibration curve was built with cadmium solutions at five different concentrations. For each binding experiment a blank experiment was planned in which the metal ion was added in the phosphate buffer and incubated for $2 \mathrm{~h}$ without addition of the wood sample. Experiments were run in triplicate.

\subsection{Evaluation of the Solubility of Woods and Tannins in the Assay Media}

Wood or tannin samples $(3 \mathrm{mg})$ were added to methanol $(20 \mathrm{~mL}), 0.3 \mathrm{M}$ acetate buffer $(\mathrm{pH} 3.6)(20 \mathrm{~mL})$, or water $(15 \mathrm{~mL})$, and taken under magnetic stirring. After 10 or 30 min the 
supernatants obtained after centrifugation $(8247 \times g$, room temperature, 15 min) were analyzed by UV-Vis spectrophotometry.

\subsection{Determination of the Amount of Tannins in the Wood Samples}

Wood or tannin samples $(10 \mathrm{mg})$ were stirred in $1 \mathrm{~mL}$ of a 1:1 $v / v$ acetone/water mixture containing $1 \%$ acetic acid [35]. After $60 \mathrm{~min}$ the supernatants obtained after centrifugation (3534× $g$, room temperature, $20 \mathrm{~min}$ ) were analyzed by UV-Vis spectrophotometry after 1:500 v/v dilution in methanol. The amount of tannins in each wood sample was determined by comparison of the absorbance at $269 \mathrm{~nm}$ (chestnut-derived samples) or $280 \mathrm{~nm}$ (quebracho-derived samples) with that measured for chestnut or quebracho tannins, respectively.

\subsection{Measurement of Total Phenolic Content (TPC)}

Wood or tannin samples $(10 \mathrm{mg})$ were stirred in DMSO $(1 \mathrm{~mL})$ for $1 \mathrm{~h}$. After centrifugation (3534 $\times g$, room temperature, $20 \mathrm{~min}$ ) 1-50 $\mu \mathrm{L}$ of the supernatant were added to $1.4 \mathrm{~mL}$ of water followed by $0.3 \mathrm{~mL}$ of a $75 \mathrm{~g} / \mathrm{L} \mathrm{Na} \mathrm{CO}_{3}$ solution and $0.1 \mathrm{~mL}$ of Folin \& Ciocalteu's reagent. After $30 \mathrm{~min}$ incubation at $40{ }^{\circ} \mathrm{C}$, absorbance at $765 \mathrm{~nm}$ was measured [36]. Gallic acid was used as reference compound. Experiments were run in triplicate.

\section{Results and Discussion}

\subsection{Antioxidant Properties of Exhausted Woods}

In a first series of experiments the antioxidant properties of chestnut wood fiber and exhausted chestnut and quebracho woods were investigated with respect to the corresponding fresh woods and tannins by widely used assays, i.e. DPPH, FRAP, superoxide scavenging, and ORAC assays following the "QUENCHER" method which allows one to measure the efficiency of electron transfer processes from a solid antioxidant [27-31].

\subsubsection{DPPH and FRAP Assays}

Table 1 reports the $\mathrm{EC}_{50}$ value, which is the dose of the material at which a $50 \% \mathrm{DPPH}$ reduction is observed, determined for tannins and wood samples in the DPPH assay. For comparison data for the reference antioxidant Trolox are also reported.

Table 1. Antioxidant properties of tannins and wood samples. ${ }^{1}$

\begin{tabular}{ccc}
\hline Sample & EC $_{\mathbf{5 0}}(\mathbf{m g} / \mathbf{m L})^{\mathbf{2}}$ (DPPH Assay) & Trolox Equivalents (FRAP Assay) \\
\hline Chestnut wood fiber & $0.054 \pm 0.003$ & $0.17 \pm 0.01$ \\
Exhausted chestnut wood & $0.436 \pm 0.003$ & $0.06 \pm 0.01$ \\
Fresh chestnut wood & $0.128 \pm 0.003$ & $0.19 \pm 0.01$ \\
Chestnut tannins & $0.019 \pm 0.002$ & $1.2 \pm 0.1$ \\
Exhausted quebracho wood & $1.14 \pm 0.04$ & $0.051 \pm 0.005$ \\
Fresh quebracho wood & $0.0990 \pm 0.0007$ & $0.08 \pm 0.01$ \\
Quebracho tannins & $0.026 \pm 0.002$ & $0.47 \pm 0.03$ \\
Trolox & $0.015 \pm 0.001$ & - \\
\hline
\end{tabular}

\footnotetext{
${ }^{1}$ Reported are the mean \pm SD values of at least three experiments. ${ }^{2} \mathrm{EC}_{50}$ is the dose of the material at which a $50 \%$ 2,2-diphenyl-1-picrylhydrazyl (DPPH) reduction is observed.
}

Among the waste materials, chestnut wood fiber displayed the most promising DPPH-reducing ability, with an $\mathrm{EC}_{50}$ value of $0.054 \mathrm{mg} / \mathrm{mL}$ that compares well with that of Trolox (3.6-fold higher). Also quebracho and particularly chestnut exhausted wood exhibited quite low $\mathrm{EC}_{50}$ values, much lower than those reported for other agro-food wastes, such as spent coffee grounds $\left(\mathrm{EC}_{50}=5.00 \mathrm{mg} / \mathrm{mL}\right)[4]$. As expected, higher antioxidant activities were exhibited by fresh wood samples, still containing tannins, and tannins themselves, characterized by $\mathrm{EC}_{50}$ values approaching that of Trolox. 
The marked differences observed in the antioxidant activity may be interpreted considering the solubility of the materials in the assay medium. Spectra shown in Figure 3a clearly indicate release of UV absorbing species in the case of pure tannins, chestnut wood fiber, and fresh woods, whereas exhausted woods do not give rise to appreciable absorbance.

The results of the FRAP assay (Table 1) looked less encouraging than those obtained in the DPPH assay, with all the waste materials exhibiting an iron(III)-reducing activity far lower than Trolox (Trolox equivalents $<<1$ ). Only chestnut tannins showed a satisfactory antioxidant power in this assay, whereas the fresh wood samples as well as quebracho tannins performed much less. Here again the antioxidant activity parallels fairly well the solubility in the medium used for the FRAP assay (Figure 3b).

To obtain information about the compounds responsible for the antioxidant properties observed, the amounts of tannins and the TPC were determined for each wood sample (Table 2). As shown in Figure 4, a good linear correlation was found between Trolox equivalents determined in the FRAP assay and the tannin content (for both the hydrolyzable and non-hydrolyzable class), but not TPC $\left(R^{2}=0.59\right)$, pointing to residual tannins as the main determinants of the iron-reducing properties. On the contrary, DPPH reducing ability was not apparently related to either TPC $\left(R^{2}=0.37\right)$ or tannin content $\left(R^{2}=0.33\right.$ and 0.50 for chestnut and quebracho-derived samples, respectively), suggesting that several factors (e.g., relative solubility in the assay medium) might be involved in the different activities observed.

The exhausted woods and the chestnut wood fiber that have been subjected to the hydrolytic treatment according to the protocol developed in previous studies $[4,25,26]$ were then evaluated for their antioxidant activity by the DPPH and FRAP assays. Data shown in Figure 5a indicate for both exhausted quebracho and chestnut woods a decrease of $\mathrm{EC}_{50}$ values in the range of $25 \%-30 \%$ compared to the values obtained for the untreated materials. By contrast no significant increase of the activity was observed in the FRAP assay following the hydrolytic treatment, apart for chestnut wood fiber, which exhibited a two-fold increase in Trolox eqs (Figure 5b).

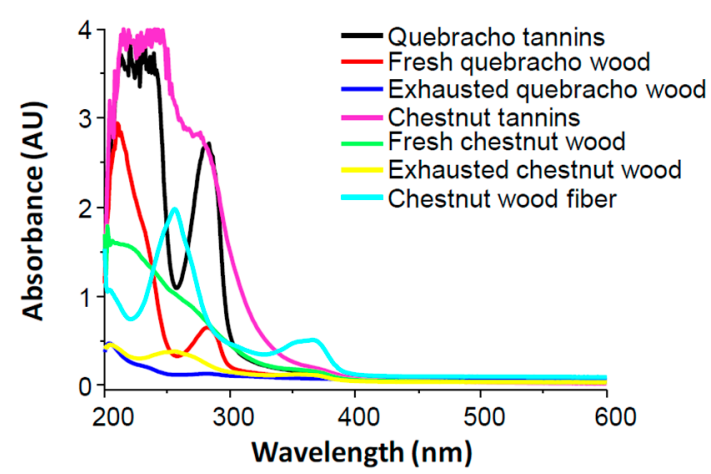

(a)

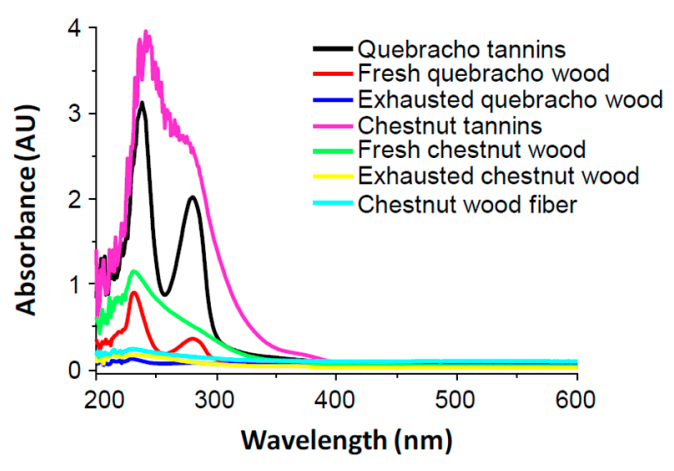

(b)

Figure 3. UV-Vis spectra of wood and tannin samples $(0.15 \mathrm{mg} / \mathrm{mL})$ in methanol (a) or $0.3 \mathrm{M}$ acetate buffer $(\mathrm{pH}=3.6)(\mathbf{b})$.

Table 2. Tannin content and total phenolic content (TPC) of wood samples.

\begin{tabular}{ccc}
\hline Sample & Tannins $(\mathbf{\%} w / w)^{\mathbf{1}}$ & TPC (mg gallic acid/g of Sample) ${ }^{\mathbf{2}}$ \\
\hline Chestnut wood fiber & 19 & $151 \pm 17$ \\
Exhausted chestnut wood & 11 & $51 \pm 3$ \\
Fresh chestnut wood & 21 & $153 \pm 9$ \\
Chestnut tannins & 100 & $457 \pm 59$ \\
Exhausted quebracho wood & 28 & $40 \pm 1$ \\
Fresh quebracho wood & 43 & $194 \pm 8$ \\
Quebracho tannins & 100 & $550 \pm 99$ \\
\hline
\end{tabular}

${ }^{1}$ Reported are the mean values of at least three experiments (SD $\left.\leq 5 \%\right) .{ }^{2}$ Reported are the mean values \pm SD of at least three experiments. 


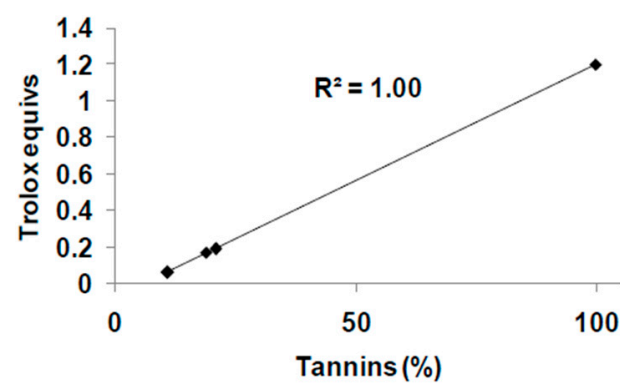

(a)

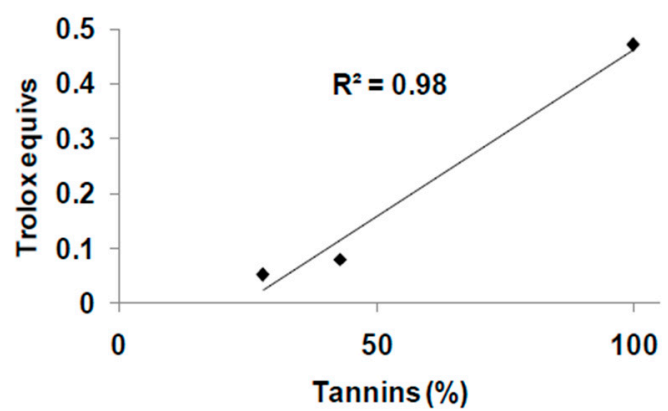

(b)

Figure 4. Correlation between tannin content and $\mathrm{Fe}^{3+}$-reducing activity of tannin and wood samples. (a) Chestnut-derived samples; (b) Quebracho-derived samples.

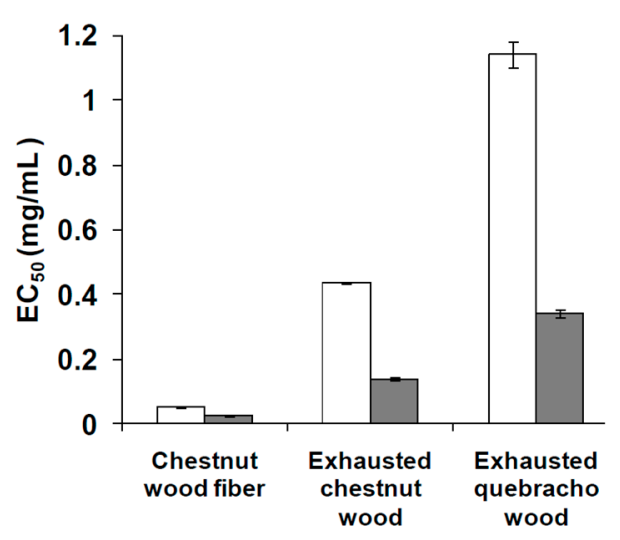

(a)

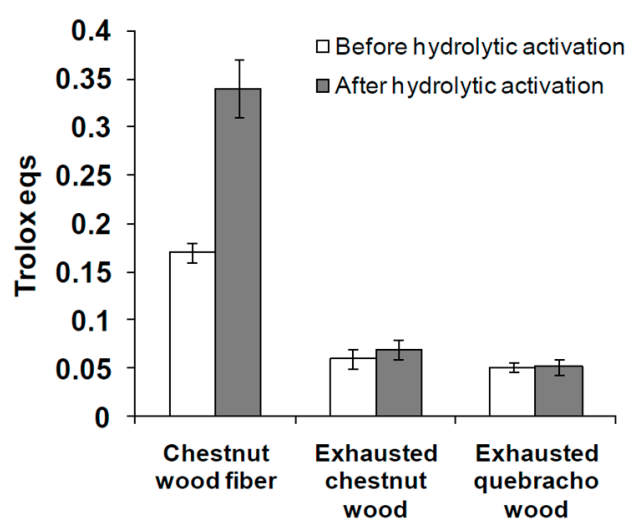

(b)

Figure 5. Antioxidant properties of exhausted wood samples before and after hydrolytic activation. (a) DPPH assay; (b) ferric reducing/antioxidant power (FRAP) assay. Reported are the mean \pm SD values of at least three experiments.

\subsubsection{Superoxide Scavenging Assay}

A very high efficiency, compared to other agri-food waste products such as spent coffee grounds [4], was observed in the superoxide scavenging assay (Figure 6), with tannins and fresh woods being always the most active samples, although in the case of chestnut-derived materials both the exhausted woods exhibited an activity comparable to that of the native sample. Only a modest correlation $\left(R^{2}=0.90\right.$ and 0.82 for chestnut and quebracho-derived samples, respectively) was found between the percentage of superoxide scavenging and the tannin content, whereas no correlation was found with TCP. Moreover, no significant improvement in the scavenging ability was detected in exhausted woods subjected to the hydrolytic treatment.

\subsubsection{ORAC Assay}

The relative fluorescence intensities determined in the ORAC assay are reported in Table 3. In this case major differences were apparent between tannins/fresh woods and exhausted samples, with the first ones almost totally inhibiting fluorescein oxidation and the second ones being completely inactive, with the only exception of chestnut wood fiber, which showed an activity comparable to that of fresh chestnut wood. Notably, in this case a good linear correlation $\left(R^{2}=0.95\right)$ was found between the antioxidant activity of the wood samples and TPC; on the contrary no significant correlation was found with the amount of residual tannins. No effect of the hydrolytic treatment was apparent either in this assay. 


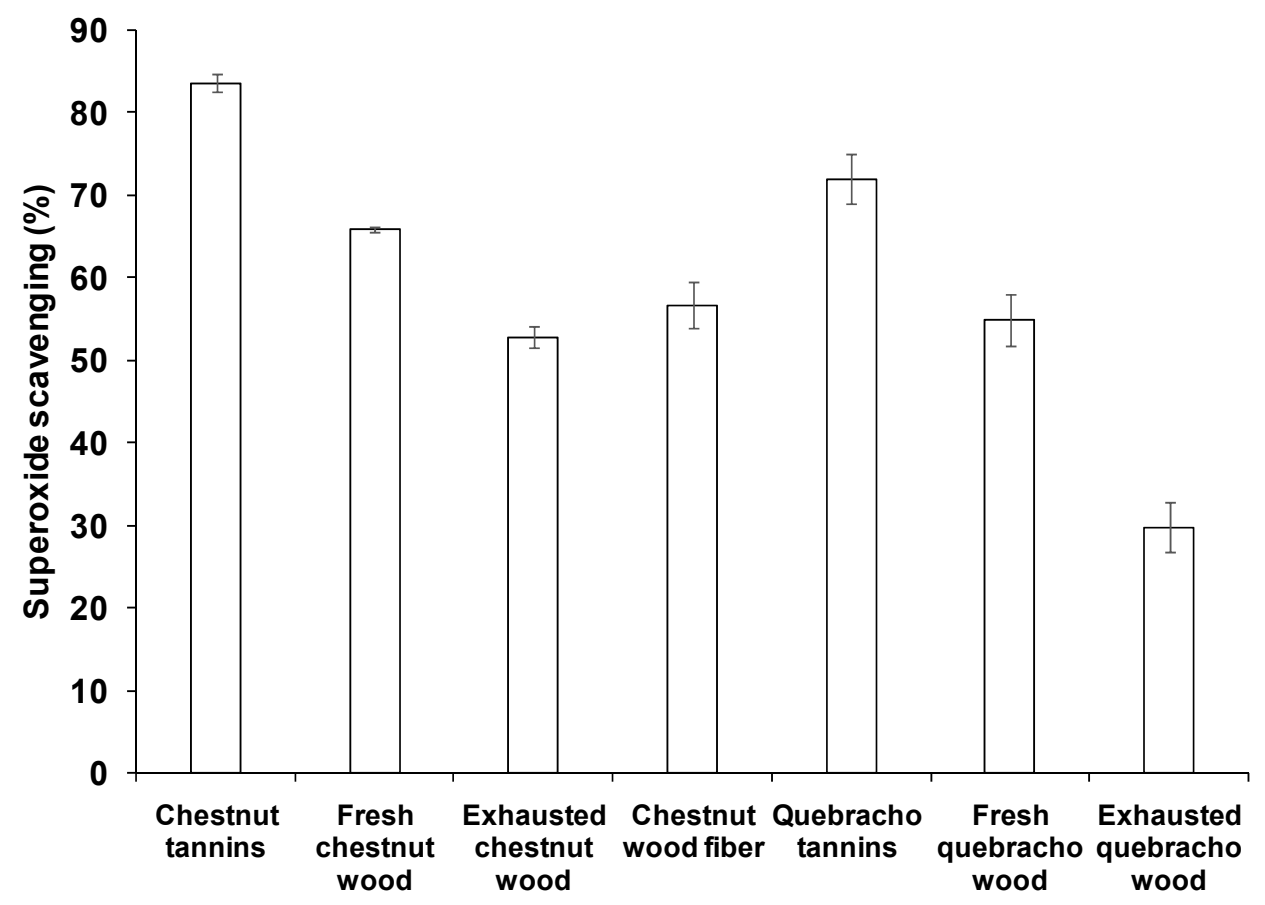

Figure 6. Superoxide scavenging activity of tannins and wood samples. Reported are the mean \pm SD values of at least three experiments.

Table 3. Activity of tannins and wood samples in the oxygen radical antioxidant capacity (ORAC) assay. ${ }^{1}$

\begin{tabular}{cc}
\hline Sample & Relative Fluorescence Intensity (\%) \\
\hline- & $0.2^{2}$ \\
Chestnut wood fiber & 86 \\
Exhausted chestnut wood & 0.5 \\
Fresh chestnut wood & 89 \\
Chestnut tannins & 81 \\
Exhausted quebracho wood & 0.2 \\
Fresh quebracho wood & 90 \\
Quebracho tannins & 100
\end{tabular}

${ }^{1}$ Reported are the mean values of at least three experiments (SD $\left.\leq 5 \%\right) .{ }^{2}$ Mixture containing only fluorescein and $\mathrm{APPH}$, without any antioxidant.

The results of the antioxidant assays further add to the potential of wood fiber as a reinforcement in polymers $[37,38]$ or as an ecological-friendly medium for horticultural practice to increase the antioxidant activity of fruit and vegetables [39].

\subsection{Pollutant Adsorption Properties of Exhausted Woods}

In a further series of experiments the adsorption capacity of the exhausted woods toward various environmental pollutants was evaluated. These included $\mathrm{MB}$, as a model organic dye, $\mathrm{NO}_{\mathrm{x}}$, that is nitric oxide (NO) and nitrogen dioxide $\left(\mathrm{NO}_{2}\right)$ which are reactive nitrogen species commonly present in cigarette smoke and exhaust gases able to induce oxidative and nitrosative stress in humans, and cadmium ions $\left(\mathrm{Cd}^{2+}\right)$, as a model of toxic heavy metals.

\subsubsection{MB Adsorption Assay}

Table 4 reports the percentages of MB adsorption by the wood samples. 
Table 4. Pollutant adsorption properties of wood samples. ${ }^{1}$

\begin{tabular}{ccc}
\hline Sample & MB Adsorption (\%) $\mathbf{~}^{\mathbf{2}}$ & $\mathbf{N O}_{\mathbf{x}}$ Scavenging (\%) $^{\mathbf{3}}$ \\
\hline Chestnut wood fiber & 100 & $32 \pm 5$ \\
Exhausted chestnut wood & $73 \pm 3$ & $23 \pm 1$ \\
Fresh chestnut wood & $79 \pm 1$ & $38+1$ \\
Exhausted quebracho wood & $77 \pm 1$ & $79 \pm 1$ \\
Fresh quebracho wood & $77 \pm 2$ & $86 \pm 5$ \\
\hline
\end{tabular}

1 Reported are the mean \pm SD values of at least three experiments. ${ }^{2}$ Determined with methylene blue (MB) at $5 \mathrm{mg} / \mathrm{L} .{ }^{3}$ Determined with $0.6 \mathrm{~mL}$ of gas.

Both exhausted chestnut and quebracho woods proved to be very efficient at a dose of $0.2 \mathrm{mg} / \mathrm{mL}$, and their adsorption properties were comparable to those exhibited by the fresh wood samples. Indeed, UV-Vis spectrophotometric analysis (Figure 7) indicated a lower solubility in the assay medium (water) of chestnut wood fiber and exhausted woods compared to the fresh samples, a feature that further adds to the potential of these materials for removal of organic compounds from waste waters.

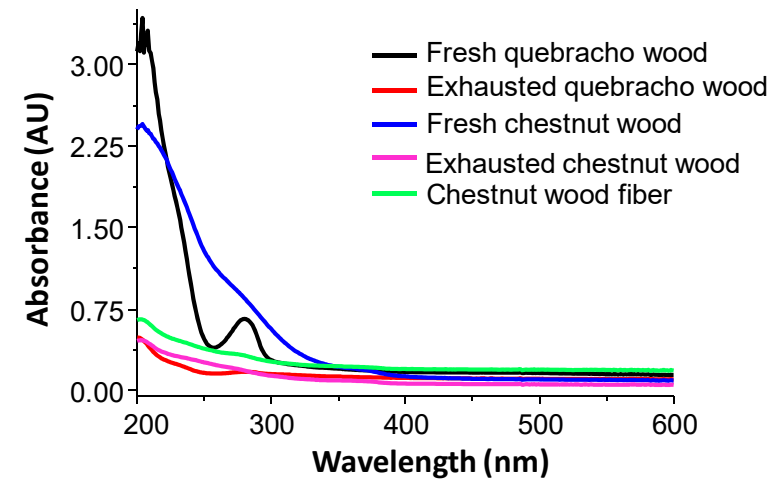

Figure 7. UV-Vis spectra of wood samples $(0.2 \mathrm{mg} / \mathrm{mL})$ in water.

A 20\%-30\% dye removal was still observed when wood samples were added to a more concentrated MB solution ( $25 \mathrm{mg} / \mathrm{mL}$ ) (Figure 8). For comparison, under the same conditions a 70\% MB removal was obtained with activated carbon, taken as a reference material. In contrast to what observed in the antioxidant assays, the MB adsorption ability of the exhausted woods did not change appreciably following to acid treatment.

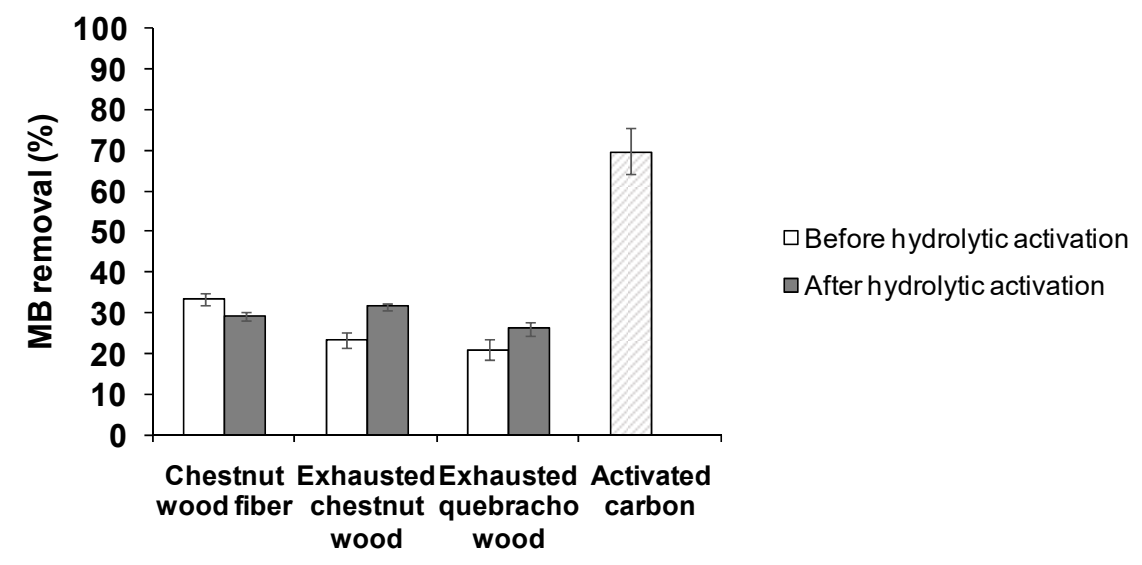

Figure 8. MB adsorption by chestnut wood fiber and exhausted woods before and after hydrolytic activation (MB starting concentration $25 \mathrm{mg} / \mathrm{L}$ ). Reported are the mean \pm SD values of at least three experiments. For comparison data relative to activated carbon are also reported. 


\subsection{2. $\mathrm{NO}_{\mathrm{x}}$ Scavenging Assay}

All the samples examined led to $>70 \%$ scavenging when $0.2 \mathrm{~mL}$ of $\mathrm{NO}_{x}$ gases were passed through $5 \mathrm{mg}$ of wood (data not shown). The percentages of $\mathrm{NO}_{\mathrm{x}}$ scavenging determined in the experiments run with $0.6 \mathrm{~mL}$ of gas are reported in Table 4, from which the superior ability of quebracho woods stands out compared to chestnut woods. These data would suggest a higher trapping efficiency of condensed tannins with respect to hydrolyzable tannins that could likely be ascribed to the reactivity of the resorcinol moieties of profisetinidins toward electrophiles like nitric oxides [40]. As observed above for MB adsorption, also in this case fresh woods were only slightly more active than exhausted samples. Notably, further to acid treatment a lower efficiency was observed for most of the tested woods (not shown), pointing to a role of the hydrolyzable cellulosic matrix in $\mathrm{NO}_{\mathrm{x}}$ scavenging.

\subsection{3. $\mathrm{Cd}^{2+}$ Removal Assay}

In a last series of experiments the ability of wood samples to remove heavy metals from aqueous solutions was investigated using $\mathrm{Cd}^{2+}$ as model ions. The assay was performed at $\mathrm{pH}$ 7.0, based on previous observations showing that natural phenolic polymers do not exhibit significant chelating properties at acidic $\mathrm{pH}$ [34]. In this case fresh woods were not evaluated because of the release of significant amounts of material under the testing conditions, likely due to solubilization of residual tannins and/or other low molecular weight components.

Based on the data reported in Figure 9, chestnut wood fiber was again the most active among the waste materials, followed by exhausted quebracho wood. An increase in $\mathrm{Cd}^{2+}$ removal was observed following hydrolytic activation for all the woods examined.

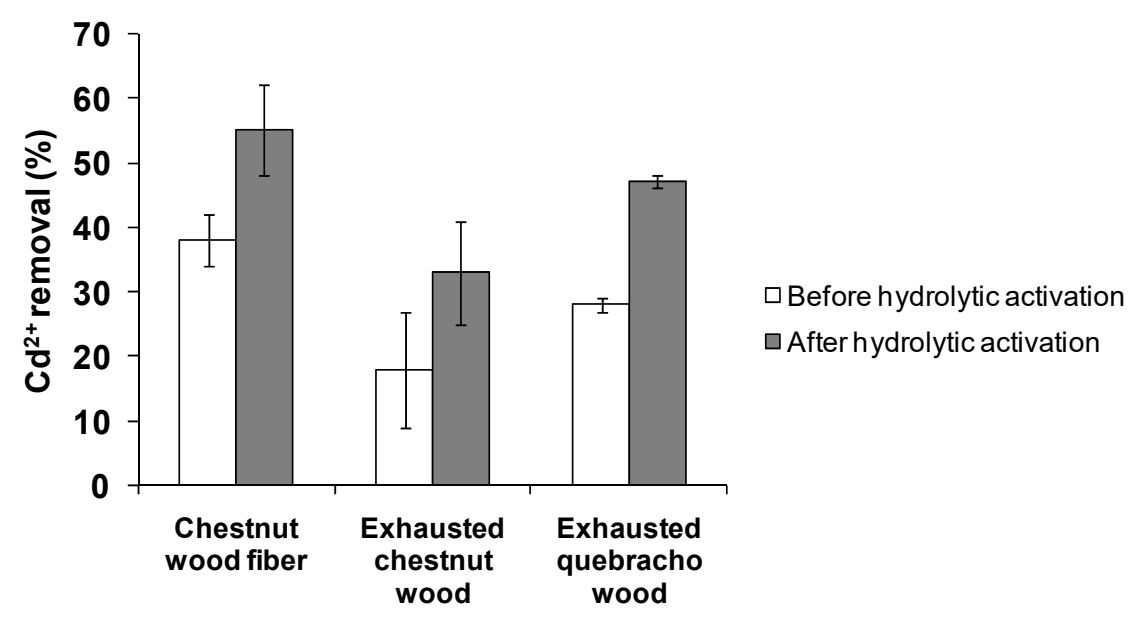

Figure 9. $\mathrm{Cd}^{2+}$ removal by exhausted woods before and after hydrolytic activation. Reported are the mean $\pm \mathrm{SD}$ values of at least three experiments.

\section{Conclusions}

Exhausted woods represent a largely available waste product of the tannin extraction process, whose practical exploitation has not yet been duly considered. As reported in the present paper, these materials exhibit good antioxidant properties in the DPPH and superoxide scavenging assay, and are also able to efficiently adsorb pollutants such as toxic gases, organic dyes and heavy metals. In particular, chestnut woods, containing mainly hydrolyzable tannins, were particularly active as antioxidants, whereas quebracho woods, characterized by the presence of condensed tannins, were found to be more effective as adsorbent materials, especially toward $\mathrm{NO}_{\mathrm{x}}$ fumes. Of particular interest is the enhancement of the antioxidant properties of exhausted woods and chestnut wood fiber following hydrolytic treatment, a methodology that had already been applied to materials containing lignins like spent coffee grounds [4] and the black sesame seed pigment [25], but also ellagitannins like pomegranate wastes [26]. An interpretation of such effects at a molecular level invoke aromatization 
and dehydration processes enhancing the hydrogen donor ability of the $\mathrm{OH}$ functionalities stemming from delocalization of the resulting phenoxyl radical over a more conjugated molecular backbone $[4,8]$. On the other hand, from consideration of the moderate weight loss further to the hydrolytic treatment it cannot be argued that the observed activation effects may simply be ascribed to removal of cellulosic or other inactive components of the materials.

Overall, these results would point to exhausted woods as novel potential functional additives to be used for example in active packaging, as food stabilizers against oxidative deterioration, or in filtering devices as pollutant removal agents.

Author Contributions: Conceptualization and writing-original draft preparation, L.P.; methodology and data curation, L.P. and M.T. (Marco Trifuoggi); investigation, F.M. and M.T. (Maria Toscanesi); resources and supervision, S.G.; writing-review and editing, A.N.

Funding: This research received no external funding.

Conflicts of Interest: The authors declare no conflict of interest.

\section{References}

1. Panzella, L.; Napolitano, A. Natural phenol polymers: Recent advances in food and health applications. Antioxidants 2017, 6, 30. [CrossRef] [PubMed]

2. Piccinino, D.; Capecchi, E.; Botta, L.; Bizzarri, B.M.; Bollella, P.; Antiochia, R.; Saladino, R. Layer-by-layer preparation of microcapsules and nanocapsules of mixed polyphenols with high antioxidant and UV-shielding properties. Biomacromolecules 2018, 19, 3883-3893. [CrossRef] [PubMed]

3. Kurisawa, M.; Chung, J.E.; Uyama, H.; Kobayashi, S. Oxidative coupling of epigallocatechin gallate amplifies antioxidant activity and inhibits xanthine oxidase activity. Chem. Commun. 2004, 294-295. [CrossRef] [PubMed]

4. Panzella, L.; Cerruti, P.; Ambrogi, V.; Agustin-Salazar, S.; D’Errico, G.; Carfagna, C.; Goya, L.; Ramos, S.; Martín, M.A.; Napolitano, A.; et al. A superior all-natural antioxidant biomaterial from spent coffee grounds for polymer stabilization, cell protection, and food lipid preservation. ACS Sustain. Chem. Eng. 2016, 4, 1169-1179. [CrossRef]

5. Panzella, L.; Pérez-Burillo, S.; Pastoriza, S.; Martín, M.Á.; Cerruti, P.; Goya, L.; Ramos, S.; Rufián-Henares, J.Á.; Napolitano, A.; d'Ischia, M. High antioxidant action and prebiotic activity of hydrolyzed spent coffee grounds (HSCG) in a simulated digestion-fermentation model: Toward the development of a novel food supplement. J. Agric. Food Chem. 2017, 65, 6452-6459. [CrossRef] [PubMed]

6. Olejar, K.J.; Ray, S.; Ricci, A.; Kilmartin, P.A. Superior antioxidant polymer films created through the incorporation of grape tannins in ethyl cellulose. Cellulose 2014, 21, 4545-4556. [CrossRef]

7. Memoli, S.; Napolitano, A.; d'Ischia, M.; Misuraca, G.; Palumbo, A.; Prota, G. Diffusible melanin-related metabolites are potent inhibitors of lipid peroxidation. Biochim. Biophys. Acta 1997, 1346, 61-68. [CrossRef]

8. Panzella, L.; D'Errico, G.; Vitiello, G.; Perfetti, M.; Alfieri, M.L.; Napolitano, A.; d'Ischia, M. Disentangling structure-dependent antioxidant mechanisms in phenolic polymers by multiparametric EPR analysis. Chem. Commun. 2018, 54, 9426-9429. [CrossRef]

9. Ambrogi, V.; Panzella, L.; Persico, P.; Cerruti, P.; Lonz, C.A.; Carfagna, C.; Verotta, L.; Caneva, E.; Napolitano, A.; d'Ischia, M. An antioxidant bioinspired phenolic polymer for efficient stabilization of polyethylene. Biomacromolecules 2014, 15, 302-310. [CrossRef]

10. Ekambaram, S.P.; Perumal, S.S.; Balakrishnan, A. Scope of hydrolysable tannins as possible antimicrobial agent. Phytother. Res. 2016, 30, 1035-1045. [CrossRef]

11. Freire, M.; Cofrades, S.; Perez-Jimenez, J.; Gomez-Estaca, J.; Jimenez-Colmenero, F.; Bou, R. Emulsion gels containing n-3 fatty acids and condensed tannins designed as functional fat replacers. Food Res. Int. 2018, 113, 465-473. [CrossRef]

12. Cheaib, D.; El Darra, N.; Rajha, H.N.; El-Ghazzawi, I.; Mouneimne, Y.; Jammoul, A.; Maroun, R.G.; Louka, N. Study of the selectivity and bioactivity of polyphenols using infrared assisted extraction from apricot pomace compared to conventional methods. Antioxidants 2018, 7, 174. [CrossRef]

13. Smeriglio, A.; Barreca, D.; Bellocco, E.; Trombetta, D. Proanthocyanidins and hydrolysable tannins: Occurrence, dietary intake and pharmacological effects. Br. J. Pharmacol. 2017, 174, 1244-1262. [CrossRef] 
14. Hagerman, A.E. Fifty years of polyphenol-protein complexes. In Recent Advances in Polyphenol Research; Cheynier, V., Sarni-Manchado, P., Quideau, S., Eds.; Wiley-Blackwell: Hoboken, NJ, USA, 2012; Volume 3, pp. 71-97.

15. Comandini, P.; Lerma-García, M.J.; Simó-Alfonso, E.F.; Toschi, T.G. Tannin analysis of chestnut bark samples (Castanea sativa Mill.) by HPLC-DAD-MS. Food Chem. 2014, 157, 290-295. [CrossRef]

16. Reid, D.G.; Bonnet, S.L.; Kemp, G.; van der Westhuizen, J.H. Analysis of commercial proanthocyanidins. Part 4: Solid state ${ }^{13} \mathrm{C}$ NMR as a tool for in situ analysis of proanthocyanidin tannins, in heartwood and bark of quebracho and acacia, and related species. Phytochemistry 2013, 94, 243-248. [CrossRef]

17. Redondo, L.M.; Chacana, P.A.; Dominguez, J.E.; Fernandez Miyakawa, M.E. Perspectives in the use of tannins as alternative to antimicrobial growth promoter factors in poultry. Front. Microbiol. 2014, $27,118$. [CrossRef]

18. Cardullo, N.; Muccilli, V.; Saletti, R.; Giovando, S.; Tringali, C. A mass spectrometry and ${ }^{1} \mathrm{H}$ NMR study of hypoglycemic and antioxidant principles from a Castanea sativa tannin employed in oenology. Food Chem. 2018, 268, 585-593. [CrossRef]

19. Molino, S.; Fernandez-Miyakawa, M.; Giovando, S.; Rufian-Henares, J.A. Study of antioxidant capacity and metabolization of quebracho and chestnut tannins through in vitro gastrointestinal digestion-fermentation. J. Funct. Foods 2018, 49, 188-195. [CrossRef]

20. Poaty, B.; Dumarcay, S.; Gerardin, P.; Perrin, D. Modification of grape seed and wood tannins to lipophilic antioxidant derivatives. Ind. Crops Prod. 2010, 31, 509-515. [CrossRef]

21. Aires, A.; Carvalho, R.; Saavedra, M.J. Valorization of solid wastes from chestnut industry processing: Extraction and optimization of polyphenols, tannins and ellagitannins and its potential for adhesives, cosmetic and pharmaceutical industry. Waste Manag. 2016, 48, 457-464. [CrossRef] [PubMed]

22. Versari, A.; du Toit, W.; Parpinello, G.P. Oenological tannins: A review. Aust. J. Grape Wine 2013, 19, 1-10. [CrossRef]

23. Campo, M.; Pinelli, P.; Romani, A. Hydrolyzable tannins from sweet chestnut fractions obtained by a sustainable and eco-friendly industrial process. Nat. Prod. Commun. 2016, 11, 409-415. [CrossRef]

24. Taflick, T.; Schwendler, L.A.; Rosa, S.M.L.; Bica, C.I.D.; Nachtigall, S.M.B. Cellulose nanocrystals from acacia bark-Influence of solvent extraction. Int. J. Biol. Macromol. 2017, 101, 553-561. [CrossRef] [PubMed]

25. Panzella, L.; Eidenberger, T.; Napolitano, A.; d'Ischia, M. Black sesame pigment: DPPH assay-guided purification, antioxidant/antinitrosating properties, and identification of a degradative structural marker. J. Agric. Food Chem. 2012, 60, 8895-8901. [CrossRef] [PubMed]

26. Verotta, L.; Panzella, L.; Antenucci, S.; Calvenzani, V.; Tomay, F.; Petroni, K.; Caneva, E.; Napolitano, A. Fermented pomegranate wastes as sustainable source of ellagic acid: Antioxidant properties, anti-inflammatory action, and controlled release under simulated digestion conditions. Food Chem. 2018, 246, 129-136. [CrossRef] [PubMed]

27. Gökmen, V.; Serpen, A.; Fogliano, V. Direct measurement of the total antioxidant capacity of foods: The 'QUENCHER' approach. Trends Food Sci. Technol. 2009, 20, 278-288. [CrossRef]

28. Goupy, P.; Dufour, C.; Loonis, M.; Dangles, O. Quantitative kinetic analysis of hydrogen transfer reactions from dietary polyphenols to the DPPH radical. J. Agric. Food Chem. 2003, 51, 615-622. [CrossRef]

29. Benzie, I.F.F.; Strain, J.J. The Ferric Reducing Ability of Plasma (FRAP) as a measure of "antioxidant power": The FRAP assay. Anal. Biochem. 1996, 239, 70-76. [CrossRef] [PubMed]

30. Xu, C.; Liu, S.; Liu, Z.; Song, F.; Liu, S. Superoxide generated by pyrogallol reduces highly water-soluble tetrazolium salt to produce a soluble formazan: A simple assay for measuring superoxide anion radical scavenging activities of biological and abiological samples. Anal. Chim. Acta 2013, 793, 53-60. [CrossRef]

31. Drinkwater, J.M.; Tsao, R.; Liu, R.; Defelice, C.; Wolyn, D.J. Effects of cooking on rutin and glutathione concentrations and antioxidant activity of green asparagus (Asparagus officinalis) spears. J. Funct. Foods 2015, 12, 342-353. [CrossRef]

32. Panzella, L.; Melone, L.; Pezzella, A.; Rossi, B.; Pastori, N.; Perfetti, M.; D’Errico, G.; Punta, C.; d'Ischia, M. Surface-functionalization of nanostructured cellulose aerogels by solid state eumelanin coating. Biomacromolecules 2016, 17, 564-571. [CrossRef]

33. Panzella, L.; Manini, P.; Crescenzi, O.; Napolitano, A.; d'Ischia, M. Nitrite-induced nitration pathways of retinoic acid, 5,6-epoxyretinoic acid, and their esters under mildly acidic conditions: Toward a reappraisal of retinoids as scavengers of reactive nitrogen species. Chem. Res. Toxicol. 2003, 16, 502-511. [CrossRef] 
34. Manini, P.; Panzella, L.; Eidenberger, T.; Giarra, A.; Cerruti, P.; Trifuoggi, M.; Napolitano, A. Efficient binding of heavy metals by black sesame pigment: Toward innovative dietary strategies to prevent bioaccumulation. J. Agric. Food Chem. 2016, 64, 890-897. [CrossRef]

35. Bosso, A.; Guaita, M.; Petrozziello, M. Influence of solvents on the composition of condensed tannins in grape pomace seed extracts. Food Chem. 2016, 207, 162-169. [CrossRef] [PubMed]

36. Seifzadeha, N.; Saharia, M.A.; Barzegara, M.; Gavlighia, H.A.; Calanib, L.; Del Rio, D.; Galaverna, G. Evaluation of polyphenolic compounds in membrane concentrated pistachio hull extract. Food Chem. 2019, 277, 398-406. [CrossRef] [PubMed]

37. Peng, Y.; Liu, R.; Cao, J. Characterization of surface chemistry and crystallization behavior of polypropylene composites reinforced with wood flour, cellulose, and lignin during accelerated weathering. Appl. Surf. Sci. 2015, 332, 253-259. [CrossRef]

38. Neagu, R.C.; Cuénoud, M.; Berthold, F.; Bourban, P.E.; Gamstedt, E.K.; Lindström, M.; Månson, J.A.E. The potential of wood fibers as reinforcement in cellular biopolymers. J. Cell. Plast. 2012, 48, 71-103. [CrossRef]

39. Gajewski, M.; Kowalczyk, K.; Bajer, M. Influence of ecological friendly mediums on chemical composition of greenhouse-grown eggplants. Ecol. Chem. Eng. A 2010, 17, 1103-1109.

40. Panzella, L.; Manini, P.; Napolitano, A.; d'Ischia, M. The acid-promoted reaction of the green tea polyphenol epigallocatechin gallate with nitrite ions. Chem. Res. Toxicol. 2005, 18, 722-729. [CrossRef]

(C) 2019 by the authors. Licensee MDPI, Basel, Switzerland. This article is an open access article distributed under the terms and conditions of the Creative Commons Attribution (CC BY) license (http://creativecommons.org/licenses/by/4.0/). 